\title{
The Implementation of Demonstration Method to Students Learning Outcomes and Interests on Colloid Materials at Class XI Science of SMA Negeri 1 Kasimbar
}

\section{*Megawati, Suherman \& Purnama Ningsih}

Pendidikan Kimia/FKIP - Universitas Tadulako, Palu - Indonesia 94119

Received 10 March 2020, Revised 09 April 2020, Accepted 12 May 2020

doi: 10.22487/j24775185.2020.v9.i2.pp87-92

\section{Abstract}

This research aims to examine the demonstration method on chemistry learning through colloid materials to learning achievement and interest of students at class XI Science of SMA Negeri 1 Kasimbar. This research was true experimental design with pretest-posttest control grup design. Sampling was carried out based on special considerations (proporsive sampling) with 21 students in class XI science 2 as sample of experimental class and 21 student of class XI science 1 as control class. This research instruments were learning achievement test and quetionnaire. Data was analyzed through descriptive statistical analysis, namely test questionnaire data, as well as inferential statistical analysis to test the hypotesis using two-party t-test. Analysis of questionnaire data of students' learning interests showed that the experimental class was in the agree category with percentage of $78.05 \%$ while the control class was in the agree category with a percentage of $60.63 \%$. Therefore, it can be concluded that demonstration method in chemistry learning on colloidal material affect learning achievement learning interest of students class XI Science of SMA Negeri 1 Kasimbar.

Keywords: Demonstration method, learning outcomes, students learning interest, colloid

\section{Pendahuluan}

Pakar pendidikan menyebutkan bahwa pendidik maupun peserta didik adalah subyek pendidikan, karena keduanya dianggap mempunyai karakter yang berperan penting dalam proses pendidikan. Adanya kesulitan siswa terhadap pelajaran kimia dapat disebabkan oleh dua faktor, yaitu internal yang berasal dari dalam diri siswa dan faktor eksternal yang berasal luar diri siswa. Faktor internal ini dipengaruhi oleh dua faktor yaitu faktor jasmani dan faktor psikologis. Faktor eksternal yang mempengaruhi siswa dalam kegiatan belajar adalah faktor keluarga, faktor sekolah, dan faktor lingkungan (Slameto, 2003).

Sains sebagai konten atau produk yang berarti bahwa dalam sains terdapat fakta, hukumhukum, prinsip dan teori yang sudah diterima kebenarannya. Dalam mata pelajaran kimia hal tersebut terdapat banyak dalam pembelajarnnya (Astuti, 2012).

Kimia merupakan salah satu mata pelajaran wajib dijenjang Sekolah Menengah Atas (SMA) pada jurusan IPA. Sehingga diharapkan siswa dapat mengkonstruksikan melalui pembelajaran dan menerapkan dalam kehidupan sehari-hari. Olehnya diperlukan suatu keterampilan berfikir yang mampu mengungkapkan secara kongkrit dan lebih detail mengenai pembelajaran kimia dan penerapannya. Sehingga hal ini membuat siswa menjadi lebih berminat dan tertarik dalam pembelajaran kimia sehingga hasil belajar akan meningkat (Sunartadi, dkk., 2014).

Menurut Muhibbin (2008), Fajri, dkk. (2012), dan Sayekti, dkk. (2012), hasil belajar merupakan suatu perubahan tingkah laku individu yang relatif menetap sebagai hasil dan interaksi dengan lingkungan yang melibatkan proses kognitif. Jadi hasil belajar atau prestasi belajar adalah suatu hasil yang telah dicapai oleh siswa setelah melakukan kegiatan belajar yang melibatkan proses kognitif dan siswa tersebut mengalami perubahan tingkah laku yang relatif menetap, hasil belajar juga tidak lepas dari minat belajar yang dimiliki oleh tiap siswa.

Menurut Ratna (2011) dan Daud (2012), ada tiga kemampuan penampilan-penampilan yang dapat diamati sebagai hasil belajar ditinjau dari segi-segi yang diharapkan dari suatu pengajaran atau instruksi yaitu kognitif, afektif dan psikomotorik.

Menurut Slameto (2003), Muldayanti (2013), dan Wahyudin (2010) yang dimaksud dengan "minat adalah suatu rasa lebih suka dan rasa ketertarikan pada suatu hal atau aktivitas, tanpa ada yang menyuruh. Minat pada dasarnya penerimaan akan suatu hubungan antara diri

*Correspondence:

Megawati

e-mail: mw5121996@gmail.com

(c) 2020 the Author(s) retain the copyright of this article. This article is published under the terms of the Creative Commons Attribution License 4.0, which permits unrestricted non-commercial use, distribution, and reproduction in any medium, provided the original work is properly cited. 
sendiri dengan sesuatu di luar diri”. Semakin kuat hubungan tersebut, maka semakin besar pula minat yang dimiliki. Selain itu, minat belajar termasuk dalam faktor intrinsik yang dapat berpengaruh terhadap hasil belajar, seseorang yang berminat terhadap suatu pembelajaran maka akan cenderung bersungguh-sungguh dalam mempelajarinya.

Menurut Rini (2008) peningkatan minat belajar siswa dapat pula dilihat dari hasil pengumpulan tugas yang diberikan dalam bentuk PR (pekerjaan rumah) secara berkelompok.

Rigiyanita (2013), Utami, dkk. (2015), dan Ma'rifatun, dkk. (2014) menyatakan penerapan metode demonstrasi efektif digunakan karena dapat meningkatkan aktivitas belajar dan prestasi belajar siswa selain itu juga dapat meningkatkan ketuntasan hasil belajar.

Asgari \& Borzooei (2013) menjelaskan "Learning outcomes emphasize three essential aspects of learning outcomes including cognitive, affective and behavior in order to prepare students for their social work and professional life" yang artinya bahwa hasil belajar menekankan pada tiga aspek penting dari hasil belajar termasuk kognitif, afektif dan perilaku dalam rangka mempersiapkan siswa untuk pekerjaan sosial dan kehidupan profesional.

Menurut Rohendi, dkk. (2010) metode demonstrasi memiliki berbagai keuntungan pada saat proses pembelajaran, diantaranya ketika seorang guru sedang melakukan proses pembelajaran didepan kelas. Dengan memanfaatkan media pembelajaran pendukung, diharapkan siswa menjadi lebih memahami tentang materi yang dijelaskan sehingga proses pembelajaran yang dilakukan siswa mendapatkan hasil yang maksimal. Termasuk media pembelajaran pendukung adalah buku ajar.

Daluba (2013) lebih lanjut menjelaskan bahwa "demonstration method as a display or an exhibition usually done by the teacher while the students watch with keen interest. He further added that, it involves showing how something works or the steps involved in the process". Yang berarti bahwa metode demonstrasi sebagai sebuah penyajian atau sebuah peragaan yang biasanya dilakukan oleh guru, sementara peserta didik memperhatikannya. Lebih lanjut ditambahkan bahwa, metode demonstrasi memperlihatkan bagaimana sesuatu bekerja atau langkah-langkah dalam suatu proses.

Effiong (2010) dalam penelitiannya menjelaskan "student centred demonstration approach involves or exhibiting objects, equipment or apparatus with the instent to showing them their ...." yang artinya metode demonstrasi yang berpusat pada siswa melibatkan siswa dalam menampilkan atau memamerkan benda-benda, peralatan atau perlengkapan dengan maksud untuk menunjukkan kepada mereka penggunaan yang benar atau menunjukkan prosedur eksperimental, dan pendekatan penyelidikan membantu peserta didik menggunakan penyelidikan dan kemampuan penalaran mereka untuk menemukan fakta-fakta dan prinsip-prinsip.

Tulisan ini dimaksudkan untuk mengetahui apakah terdapat perbedaan hasil belajar menggunakan metode demonstrasi dan metode konvensional, serta tujuan kedua untuk mendeskripsikan minat belajar siswa.

\section{Metode}

Desain yang digunakan dalam penelitian ini adalah true experimental design yaitu penelitian dengan melihat perbedaan pre-test maupun posttest antara kelas eksperimen dan kelas kontrol.

Penelitian ini dilaksanakan di SMA Negeri 1 Kasimbar, pada kelas XI IPA dengan jumlah sampel 21 siswa sebagai kelas eksperimen (XI IPA 2) dan 21 siswa sebagai kelas kontrol (XI IPA 1). Teknik pengumpulan sampel yang digunakan adalah purposive sampling, yaitu teknik penentuan sampel dengan pertimbangan sistem penempatan siswa di dalam kelas dan guru mata pelajaran yang sama.

Instrumen tes yang telah divalidasi oleh validator kemudian diujicobakan di lapangan yang dilakukan di SMA Negeri 1 Kasimbar pada siswa kelas XII IPA yang berjumlah 20 siswa. Hasil uji coba tes tersebut kemudian dianalisis dengan menggunakan aplikasi AnatesV4, AnatesV4 merupakan sebuah program aplikas komputer bertujuan untuk mengetahui hasil dari validitas, reliabilitas, daya pembeda dan tingkat kesukaran dari tiap-tiap soal instrumen yang akan langsung ditampilkan hasilnya (Purwanto, 2013). Hasil analisis instrumen tes yang diperoleh dari 40 soal yang diuji cobakan diperoleh 20 soal yang layak digunakan. Analisis data dilakukan menggunakan uji statistik $t$ dua pihak.

\section{Hasil dan Pembahasan}

Berdasarkan penelitian yang dilakukan maka diperoleh hasil pengujian normalitas, homogenitas dan hipotesis penelitian dari data tes akhir pada kelas eksperimen dan kelas kontrol.

Uji normalitas data digunakan untuk mengetahui apakah populasi data berdistribusi normal atau tidak. Data yang diuji normalitas adalah data hasil post-test pada kelas eksperimen dan kelas kontrol. Pengujian normalitas data posttest pada penelitian menggunakan uji Chi-kuadrat dengan kriteria penerimaan $\chi^{2}$ hitung $<\chi^{2}$ Tabel, taraf signifikan $\alpha=0.05$, dan derajat kebebasan $\mathrm{dk}=\mathrm{k}-$ 3. Dari Tabel 1 terlihat bahwa nilai $\chi^{2}$ hitung kelas eksperimen maupun kelas kontrol lebih kecil daripada nilai $\chi_{\text {tabel. }}^{2}$ Artinya, hasil ini menunjukan bahwa data post-test kelas eksperimen maupun kelas kontrol terdistribusi normal. 
Tabel 1. Normalitas distribusi tes awal dan tes akhir pada kelas eksperimen dan kelas kontrol

\begin{tabular}{ll}
\hline \multirow{2}{*}{ Uraian } & \multicolumn{2}{c}{ Kelas } \\
\cline { 2 - 3 } & Eksperimen Kontrol \\
\hline
\end{tabular}

$\begin{array}{ccc}\text { Sampel } & 21 & 21 \\ \chi^{2} \text { hitung } & 4.65 & 5.53 \\ \chi^{2} \text { tabel } & 5.99 & 5.99\end{array}$

Uji homogenitas digunakan untuk menentukan apakah data yang diperoleh homogen dengan kriteria pengujian $\mathrm{H}_{0}$ ditolak jika $\mathrm{F} \geq \mathrm{F}$ $(1 / 2 \alpha)\left(V_{1}, V_{2}\right)$ dengan peluang $\alpha=0.05$ (Subana \& Sudrajat, 2001). Dari hasil pengujian disimpulkan bahwa tidak terdapat perbedaan varian antara kelas kontrol dan kelas eksperimen sehingga data bersifat homogen dengan nilai $\mathrm{F}_{\text {hitung }}=1.03<\mathrm{F}_{\text {tabel }}=2.12$.

Setelah terpenuhi uji normalitas dan uji homogenitas, kemudian dilakukan uji hipotesis dengan menggunakan uji $\mathrm{t}$ dua pihak. Harga $\mathrm{t}$ (0.95) dengan $\mathrm{dk}$ (derajat kebebasan) $=40$ dari daftar distribusi siswa adalah 1.68, dengan kriteria pengujian yaitu jika- $\mathrm{t}_{\text {tabel }} \leq \mathrm{t}_{\text {hitung }} \leq+\mathrm{t}_{\text {tabel }}(1-\alpha)$, $\left(\mathrm{n}_{1}+\mathrm{n}_{2}-2\right)$ (Subana \& Sudrajat, 2001). Berdasarkan hasil pengujian diperoleh $-1.68 \leq$ $2.84 \geq+1.68$ berada pada daerah penolakan $\mathrm{H}_{0}$ dan $\mathrm{H}_{1}$ diterima, yaitu menunjukkan terdapat perbedaan hasil belajar pada materi koloid dengan menggunakan metode demonstrasi dan menggunakan metode konvensional.

Kuesioner (angket) digunakan untuk mengetahui peningkatan minat belajar siswa melalui pertanyaan-pertanyaan. Berdasarkan penelitian yang telah dilakukan didapatkan data kuesioner untuk minat belajar siswa kelas eksperimen dan kelas kontrol pada Tabel 2.

Tabel 2 Data hasil minat belajar siswa

\begin{tabular}{lcccc}
\hline Uraian & \multicolumn{2}{c}{ Kuesioner awal } & \multicolumn{2}{c}{ Kuesioner akhir } \\
\cline { 2 - 5 } & Eks & Kont & Eks & Kont \\
\hline Sampel & 21 & 21 & 21 & 2141. \\
Skor rendah & 40.95 & 48.57 & 58.10 & 90 \\
Skor tinggi & 65.71 & 74.29 & 84.76 & 74.29 \\
\% Rata-rata & 57.78 & 59.71 & 78.05 & 60.63 \\
Sikap & Ragu-ragu & Ragu-ragu & setuju & setuju \\
\hline
\end{tabular}

Penelitian yang telah dilakukan menggunakan dua instrumen yaitu tes hasil belajar yang bertujuan untuk melihat perbedaan kemampuan awal siswa sebelum proses pembelajaran dan setelah pembelajaran apakah mengalami peningkatan atau tidak, instrumen tes hasil belajar dibuat dalam bentuk soal sebanyak 20 item yang terlebih dahulu divalidasi sebelum digunakan. Instrumen kedua yang digunakan yaitu kuesioner (angket) yang digunakan untuk mendapatkan data minat belajar siswa, instrumen tersebut dibuat dalam 18 item pertanyaan dengan memperhatikan faktor eksternal dan faktor internal sebelum digunakan kuesioner tersebut divalidasi terlebih dahulu oleh validator.

\section{Tes Hasil Belajar}

Tes hasil belajar siswa digunakan untuk melihat nilai sebelum dan sesudah proses pembelajaran, tes hasil belajar diukur dengan menggunakan instrumen tes tertulis yang telah divalidasi terlebih dahulu. Sebelum divalidasi soal disajikan sejumlah 40 soal mulai dari tingkatan pengetahuan (C1), pemahaman (C2), aplikasi
(C3), analisis (C4) dan evaluasi (C5). Setelah divalidasi diperoleh 20 soal yang valid dengan tingkat kesukaran sebagai proporsi peserta tes yang menjawab benar yang dianjurkan yaitu 0.31 0.70 .

Daya pembeda digunakan untuk melihat kemampuan butir soal membedakan siswa yang mempunyai kemampuan tinggi dan rendah dan kriteria yang digunakan dalam menentukan daya pembeda butir soal yaitu 0.21-1.00. Reliabilitas berhubungan dengan kemampuan tes hasil belajar sebagai alat untuk memberikan hasil pengukuran yang relatif tetap dan konsisten kriteria yang digunakan dalam reliabilitas yaitu jika nilai $\mathrm{R}=$ 0.41-1.00. Tingkat kesukaran, daya pembeda dan reliabilitas tes dapat diukur dengan aplikasi AnatesV4. Setelah soal memenuhi syarat kemudian barulah diberikan kepada siswa sebelum (pre-test) dan sesudah (post-tes) diberikan pembelajaran. Hasil tes tersebut kemudian dianalisis menggunakan statistik inferensial untuk melihat bagaimana metode pembelajaran terhadap hasil belajar siswa. 
Berdasarkan data yang diperoleh dari uji statistik inferensial uji normalitas kelas eksperimen diperoleh $\chi^{2}$ hitung $=4.65$ sedangkan untuk kelas kontrol $\chi^{2}$ hitung $=5.53$, keduanya memiliki nilai kurang dari $\chi_{\text {tabel }}^{2}=5.99$ yang berarti data terdistribusi normal. Untuk uji homogenitas diperoleh $\mathrm{F}_{\text {hitung }}=1.03<\mathrm{F}_{\text {tabel }}=2.12$ yang berarti data tersebut homogen. Sedangkan untuk uji hipotesis diperoleh diperoleh $-1.68 \leq$ $2.84 \geq+1.68$ menunjukkan terdapat perbedaan hasil belajar pada materi koloid dengan menggunakan metode demonstrasi dan menggunakan metode konvensional. Metode pembelajaran demonstrasi dapat memberikan perbedaan hasil belajar siswa sebagai akibat dari kelebihan-kelebihan yang menjadi ciri khas dari metode pembelajaran demonstrasi. Adapun manfaat psikologi dari metode demonstrasi dalam proses pembelajaran yaitu siswa akan dapat memusatkan perhatian pada objek yang akan didemonstrasikan, proses pembelajaran akan lebih terarah pada materi yang dipelajari, pengalaman dan kesan akibat dari demonstrasi yang dilakukan akan lebih melekat dimemori siswa. Kondisi belajar mengajar yang efektif merupakan pertanda adanya minat dan perhatian siswa dalam belajar karena minat tersebut memiliki pengaruh yang besar terhadap belajar siswa karena dengan minat siswa akan melakukan sesuatu yang diminatinya (Daryanto \& Rahardjo, 2012)

Keterlibatan siswa dalam belajar erat kaitannya dengan sifat-sifat murid, baik yang bersifat kognitif seperti kecerdasan dan bakat maupun yang bersifat afektif seperti motivasi, keingintahuan dan rasa percaya diri.

Hasil pengujian hipotesis yang menunjukkan perbedaan hasil belajar pada metode demonstrasi dari pada metode konvensional. Hipotesis tersebut didukung oleh bukti data yang diperoleh pada tes awal dan tes akhir siswa yang menunjukkan peningkatan pada kelas yang diterapkan metode demonstrasi.

\section{Minat Belajar}

Menurut Muldayanti (2013) minat adalah kecenderungan dan kegairahan yang tinggi atau keinginan yang besar terhadap sesuatu. Minat belajar siswa mempengaruhi prestasi belajar dikarenakan faktor kepercayaan diri siswa dan adaptasi siswa dalam menerima metode pembelajaran. Daryanto \& Rahardjo (2012) mengungkapkan bahwa minat siswa merupakan faktor utama yang menentukan derajat keaktifan belajar siswa.

Instrumen yang digunakan dalam mendapatkan data minat belajar yaitu kuesioner (angket) yang terlebih dulu divalidasi. Dalam penyusunan pertanyaan-pertanyaan dalam kuesioner tersebut memperhatikan dua faktor yaitu faktor pendorong dari dalam (internal) dan faktor pendorong dari luar (eksternal) selain itu juga ada pertanyaan kategori pertanyaan positif, pertanyaan netral dan pertanyaan negatif. contoh dari pertanyaan eksternal kategori positif yaitu "pelajaran kimia banyak berhubungan dengan kehidupan sehari-hari sehingga saya senang belajar kimia", contoh dari pertanyaan internal kategori netral yaitu "pelajaran kimia sangat menarik sehingga saya sering mencari tahu tentang ilmu kimia lewat media internet", contoh pertanyaan eksternal kategori negatif yaitu "saya sering menghayal ketika pelajaran kimia berlangsung karena metode pembelajaran yang digunakan tidak kreatif".

Pertanyaan-pertanyaan yang disajikan berjumlah 18 item diberikan kepada kelas kontrol dengan julah siswa 21 orang dan kepada kelas eksperimen dengan jumlah siswa 21 orang, kuesioner pertanyaan tersebut diberikan kepada siswa sebanyak dua kali yaitu pada saat pertemuan pertama sebelum proses pembelajaran tujuannya yaitu untuk mengetahui bagaimana pandangan awal siswa mengenai pembelajaran kimia, pemberian kuesioner kedua pada saat selesai proses pembelajaran dengan tujuan untuk mengetahui bagaimana pandangan siswa mengenai pembelajaran kimia setelah diberikan perlakuan pada saat pembelajaran berlangsung.

Kelas kontrol dan kelas eksperimen samasama menunjukkan persetujuan pada kategori setuju, namun persentase dari eksperimen lebih tinggi dibandingkan dengan kelas kontrol yaitu berkisar sekitar $17.42 \%$. Hal ini karena siswa banyak memberikan persetujuan yang baik pada pertanyaan kategori positif dan kategori netral dengan tingkat persetujuan tertinggi yaitu "sangat setuju" dengan skor tertinggi untuk sangat setuju yaitu 5 , untuk tingkat persetujuan berikutnya yaitu "setuju" dengan skor tertingginya yaitu 4 , untuk tingkat persetujuan "ragu-ragu" skornya 3 dan seterusnya.

Berdasarkan hasil penelitian yang telah dilakukan maka dapat disimpulkan bahwa metode demonstrasi pada pembelajaran kimia melalui materi koloid dapat memberikan perbedaan hasil belajar serta dapat dapat memberikan deskripsi mengenai minat belajar siswa kelas XI IPA SMA Negeri 1 Kasimbar. Hal ini juga sesuai dengan pendapat Aritonang (2008) yang menyatakan bahwa faktor-faktor yang mempengaruhi hasil belajar siswa dari dalam adalah minat dan motivasi belajar siswa.

\section{Kesimpulan}

Penggunaan metode demonstrasi pada pembelajaran kimia melaui materi koloid dapat meningkatkan hasil belajar dan minat belajar siswa kelas XI IPA SMA Negeri 1 Kasimbar, dilihat dari perolehan nilai rata-rata post-test tiap kelas, yaitu untuk kelas eksperimen adalah 64.29 dan kelas kontrol adalah 62.14. menunjukkan adanya perbedaan hasil belajar pada materi koloid dengan menggunakan metode demonstrasi dan menggunakan metode konvensional. Dapat pula 
dilihat dari hasil analisis kuesioner (angket) minat belajar siswa berdasarkan perhitungan statistik deskriptif yang menunjukkan bahwa kelas eksperimen berada pada kategori setuju dengan persentase $78.05 \%$ sedangkan untuk kelas kontrol yaitu $60.63 \%$ juga berada pada kategori setuju. Sehingga dapat disimpulkan bahwa metode demonstrasi pada pembelajaran kimia melalui materi koloid dapat memberikan perbedaan hasil belajar serta dapat memberikan deskripsi mengenai minat belajar siswa kelas XI IPA SMA Negeri 1 Kasimbar.

\section{Ucapan Terima Kasih}

Penulis mengucapkan rasa terimakasih kepada semua pihak yang telah membantu suksesnya penelitian terutama untuk kepala sekolah SMA Negeri 1 Kasimbar bapak Irwan, wakil kepala sekolah bidang kesiswaan bapak Umar Amir, ibu Muliati guru mata pelajaran kimia, dan semua yang telah banyak membantu.

\section{Referensi}

Aritonang, K. T. (2008). Minat dan motivasi dalam meningkatkan hasil belajar siswa. Jurnal Pendidikan Penabur, 10(7), 11-21.

Asgari, M., \& Borzooei, M. (2013). Evaluating the learning outcome of international students as education tourists. Journal of Business Studies Quarterly, 5(2), 130-140.

Astuti, R. (2012). Pembelajaran IPA dengan pendekatan keterampilan proses sains menggunakan metode eksperimen bebas termodifikasi dan eksperimen terbimbing ditinjau dari sikap ilmia dan motivasi belajar siswa. Jurnal Inkuiri, 1(1), 51-59.

Daluba, N. E. (2013). Effect of demonstration method of teaching on students' achievement in agricultural science. World Journal of Education, 3(6), 1-7.

Daryanto, \& Rahardjo. (2012). Model pembelajaran inovatif. Yogyakarta: Gava Media.

Daud, F. (2012). Pengaruh kecerdasan emosional (EQ) dan motivasi belajar terhadap hasil belajar biologi siswa SMA 3 Negeri Kota. Jurnal Pendidikan dan Pembelajaran, 2(19), 243-255.

Effiong, U. M. (2010). Effect of guideddiscovery, student-centred demonstration and the expository instructional strategies on students' performance chemistry. $A n$ International Multi-Disciplinary Journal Ethiopia, 4(4), 389-398.

Fajri, L., Kus, S. M., \& Agung, N. C. S. (2012). Upaya peningkatan proses dan hasil belajar kimia materi koloid melalui pembelajaran kooperatif tipe TGT (teams games tournament) dilengkapi dengan teka-teki silang bagi siswa kelas XI IPA 4 SMA Negeri
Boyolali pada semester genap tahun ajaran 2011/2012. Jurnal Pendidikan Kimia, 1(1), 89-96.

Ma'rifatun, D., Kus, S. M., \& Suryadi, B. U. (2014). Pengaruh model pembelajaran predict observe explaint (POE) menggunakan metode eksperimen dan demonstrasi terhadap prestasi belajar siswa pada pokok bahasan larutan penyangga kelas XI SMA Al-Islam 1 Surakarta tahun pelajaran 2013/2014. Jurnal Pendidikan Kimia, 3(3), 11-16.

Muhibbin, S. (2008). Psikologi pendidikan dengan pendekatan baru. Bandung: PT Remaja Rosdakarya.

Muldayanti, N. D. (2013). Pembelajaran biologi model STAD dan TGT ditinjau dari keingintahuan dan minat belajar siswa. Jurnal Pendidikan IPA Indonesia, 2(1), 12-17.

Purwanto. (2013). Evaluasi hasil belajar. Yogyakarta: Pustaka Pelajar.

Ratna, W. D. (2011). Teori belajar dan pembelajaran. Jakarta: PT Glora Aksara Pratama.

Rigiyanita, A. I., Haryono., \& Suryadi, B. U. (2013). Efektivitas model pembelajaran contextual teaching and learning disertai dengan kegiatan demonstrasi terhadap prestasi belajar asam, basa dan garam. Jurnal Pendidikan Kimia, 2(2), 50-55.

Rini, M. N. (2008). Peningkatan minat belajar kimia siswa melalui modul komik pada kelas $\mathrm{X}$ MAN 2 Wates Kulon Progo. Prosiding Seminar Nasional Penelitian, Pendidikan dan Penerapan MIPA, 198-204. Yogyakarta.

Rohendi, D., Sutarno, H., \& Ginanjar, M. A. (2010). Efektivitas metode pembelajaran demonstrasi terhadap peningkatan hasil belajar siswa kelas X pada mata pelajaran keterampilan komputer dan pengelolaan informasi di sekolah menengah kejuruan. Jurnal Pendidikan Teknologi Informasi dan Komunikasi, 15(1), 16-18.

Sayekti, I. K., Sarwanto., \& Suparmi. (2012). Pembelajaran IPA menggunakan pendekatan inkuiri terbimbing melalui metode eksperimen dan demonstrasi ditinjau dari kemampuan analisis dan sikap ilmiah siswa. Jurnal Inkuiri, 2(1), 142-153.

Slameto. (2003). Belajar dan faktor-faktor yang mempengaruhinya. Jakarta: PT Rineka Cipta.

Subana, \& Sudrajat. (2001). Dasar-dasar penelitian ilmiah. Bandung: CV Pustaka Setia.

Sunartadi, S., Sukardjo, J. S., \& Nurhayati, D. (2014). Studi komparasi pembelajaran number head together (NHT) dengan menggunakan media demonstrasi dan percobaan pada pokok bahasan asam, basa dan garam terhadap prestasi belajar siswa kelas VII SMP Negeri 2 Sawit Boyolali tahun 
pelajaran 2012/2013. Jurnal Pendidikan Kimia, 3(4), 24-30.

Utami, D. D., Hastuti, B., \& Redjeki, T. (2015). Upaya peningkatan aktivitas dan prestasi belajar siswa kelas XI IPA 2 dengan menggunakan model pembelajaran kooperatif tipe team assisted individualization (TAI) berbantuan demonstrasi pada materi hidrolisis garam di SMA Negeri 1 Banyudono Boyolali. Jurnal Pendidikan Kimia, 4(1), 157-164.

Wahyudin, \& Sutikno, A. I. (2010). Keefektifan pembelajaran berbantuan multimedia menggunakan metode inkuiri terbimbing untuk meningkatkan minat dan pemahan siswa. Jurnal Pendidikan Fisika, 6(1), 58-62. 